\title{
INDEPENDENT AND SIMULTANEOUS MODELING OF BIOMASS AND CARBON OF Guinean Elaeis
}

\author{
Carlos Roberto Sanquetta ${ }^{1}$, Myrcia Minatti ${ }^{1,}$ Sérgio Costa Junior ${ }^{1}$, Jonathan William Trautenmüller ${ }^{2 *}$, Ana Paula \\ Dalla Corte ${ }^{1}$ \\ ${ }^{1}$ Federal University of Paraná, Department of Forest Science, Curitiba, Paraná, Brazil - carlossanquetta@ gmail.com; \\ myrciaminatti@gmail.com; o.sergio.costa@gmail.com; anapaulacorte@gmail.com. \\ 2*Federal University of Paraná (UFPR), Department of Phytotechnology and Phytosanitary, Curitiba, Paraná, Brazil - jwtraute@ gmail.com*,
}

Received for publication: 12/04/2018 - Accepted for publication: 12/07/2018

\begin{abstract}
Resumo
Modelagem independente e simultânea da biomassa e carbono de Elaeis guineensis. O objetivo deste estudo foi modelar o estoque de biomassa total acima do solo e por componentes estipe e copa nos cultivos de dendê por estimativa independente e simultânea em diferentes idades de cultivo. A coleta foi realizada em plantios comerciais de dendê em Taperoá, na Bahia. Cinco modelos foram testados, a escolha do melhor baseou-se nos critérios estatísticos $\mathrm{R}^{2}$ ajustado, Syx (\%), CIA e análise gráfica dos resíduos para os ajustes independentes, e as melhores equações para cada componente foram ajustadas simultaneamente. A biomassa e o carbono obtiveram boas correlações com a altura de estipe e altura total, o que foi identificado pela análise de trilha. A estimativa simultânea demonstrou resultados satisfatórios nos critérios estatísticos, quando comparados com as estimativas independentes, sendo para o total ou por componentes.

Palavras-chave: ajuste simultâneo, análise de trilha, inventário florestal.
\end{abstract}

\begin{abstract}
The objective of this study was to perform and evaluate the modeling for individual and aboveground components of biomass and carbon in palm crops by independent and simultaneous estimation in different cultivation ages. The data collection was performed in a commercial pam crop in Taperoá, state of Bahia. Five models were tested and the best one was chosen based on statistical criteria of adjusted $\mathrm{R}^{2}$, Syx (\%), AIC and graphical analysis of the residuals for independent adjustments and the best equations for each component were adjusted simultaneously. Biomass and carbon showed good correlation with the stipe height and total height, which was identified by path analysis. The simultaneous estimation demonstrated satisfactory results in the statistical criteria when compared to the independent estimates, being it total or by compartments.

Keywords: simultaneous adjustment, path analysis, forest inventory.
\end{abstract}

\section{INTRODUCTION}

The use of fossil fuels for the energy production is being increasingly questioned by several sectors of society. For Borges et al. (2016), the substitution of these fuels for renewable energy sources is the most appropriate option, since it has a lower environmental impact. According to Goldemberg and Villanueva (2003), when the source of renewable energy is biomass, there is an increase in the generation of direct and indirect jobs, promoting an improvement in quality of life, social inclusion and regional development.

In Northern Brazil, the palm (Elaeis Guineans Jacq.), known as "dendê", is one of the species cultivated for the purpose of producing biomass (raw material) for energy production. In this sense, according to Lorenzi et al. (2004), this palm tree has an average diameter of 35 centimeters and a height ranging from 15 to 20 meters, with large and numerous leaves of 3 to 4 meters in length. It is native from Africa and known for producing fruits with high oil content, presenting high productivity per unit area, up to 10 times more productive than soybean (OLIVEIRA et al., 2017). Despite of its use in the production of biofuels, palm oil is destinated to the use in food, steel, pharmaceutical, cosmetic and paint industries (RIOS et al., 2012). Thus, in addition to the environmental and social benefits provided by oil production, the palm produces a large amount of sprout biomass and foliage that can be used to generate energy.

In the case of a raw material of plant origin, carbon dioxide emissions from combustion contribute to the carbon cycle in nature, consisting of a source of renewable energy. According to Sanquetta et al. (2015), palm crops, besides storing carbon in their biomass, also contribute to the mitigation of emissions related to land use. Therefore, it is important to know the biomass and carbon stocks in each component (sprout and foliage). The quantification of these variables is essential in order to plan the use of this biomass as an energy source, as well as to estimate the amount of carbon dioxide that will cease to be emitted from non-renewable sources, helping to mitigate the effects of global warming.

FLORESTA, Curitiba, PR, v. 49, n. 3, p. 421 - 430, jul/set 2019.

Sanquetta, C. R. et.al.

ISSN eletrônico 1982-4688

DOI: $10.5380 /$ rf.v49 i3.58897 
According to Sanquetta et al. (2004), different approaches to biomass and carbon estimates exist. Generally, methodologies are separated into direct methods and indirect methods. Using the direct method involves performing destructive measures, i.e., performing biomass sampling in the field, which presents a high cost. The indirect method, frequently more used, is based on the allometric relationships in order to support the estimates made (CORTE; SILVA; SANQUETTA, 2012). In this way, one of the ways to know the biomass and carbon stock in trees is through the development of mathematical models for their estimates (SANQUETTA et al., 2004). For Ribeiro et al. (2011), parsimonious, easy-to-interpret and high-precision models, employing relevant and easily obtainable independent variables should be chosen.

Track analysis is one of the techniques that can be used to select independent variables to participate in modeling. This technique, based on the principle of linear regression, allows the partitioning of the linear correlation coefficient in direct and indirect effects of the independent variables, contributing, then, to the selection of variables with better explanatory capacity (OLIVOTO et al., 2017). Additionally, this technique has been widely used in studies related to the selection of variables with greater explanatory capacity of the interest viable in genetic breeding programs (OLIVOTO et al., 2017).

When it is desired to model the biomass, stocks total and their components, one of the properties that must be considered is the additivity, since it ensures consistent functions between each other (PARRESOL, 2001). According to this author, it is essential that the component equations are additive, that is, occurring compatibility of biomass estimates of components with total biomass. This presupposes that the equations for the components of biomass and total biomass must be estimated together, in other words, a simultaneous estimation, considering the principle of additivity of Kozak (1970). Moreover, Behling et al. (2018), in studies with black wattle biomass, found the advantage of not having distortions between the sum of the equations for each compartment and the equation for the total when applied to the simultaneous adjustment technique because it guarantees the overall quality of the prediction of the biomass for the compartments and also for the total.

Considering the hypothesis that the simultaneous adjustment improves the statistical parameters of the biomass and carbon equations in relation to the independent adjustments, the objective of the present study was to model the canopy biomass (foliage), stem (stipe) and total biomass above the soil of palm individuals by means of independent and simultaneous estimates (principle of additivity) at different ages of cultivation. And also, evaluate the correlation of dendrometric variables with biomass and carbon in palm crops.

As a consequence, this will help ensure that biomass and carbon stocks of palm crops can be estimated quickly, accurately, and at low cost by providing information for the planning of palm biomass use. According to Soares, Leite and Gorgens (2005), this information is also fundamental for the elaboration of afforestation or reforestation projects, aimed at mitigating climate change.

\section{MATERIAL AND METHODS}

The study was developed in commercial "dendê" plantations (Guinean Elaeis Jacq.), with central coordinates $\left(13^{\circ} 33^{\prime} 40^{\prime \prime}\right.$ South and $39^{\circ} 06^{\prime} 50^{\prime \prime}$ West and at an altitude of $\left.40 \mathrm{~m}\right)$, located in the municipality of Taperoá, south state of Bahia, Brazil (IBGE, 2012). The climate of the region, according to Köppen, is Af, Tropical, hot and humid, with rainfall regime balanced between the months of April and November, showing drought between December and March, with annual average precipitation between 1.600 and $1.900 \mathrm{~mm}$ and average temperature between 24 and $26^{\circ} \mathrm{C}$ (ALVARES et al., 2013). The soils of the region are classified as dystrophic yellow latosol (SANTOS et al., 2013).

It was selected 33 representative palm trees in three stands corresponding to different ages (10 - 36 years old) with a spacing of $9 \times 9 \mathrm{~m}$, maintaining a distance of $100 \mathrm{~m}$ between the samples. Average trees were selected in each parcel of land. All the palms presented normal phenotype, without damage or other defects caused by physical or pathological agents. The palms were cut and separated into stipe (stem) and foliage. In addition to the biomass, the diameter at breast height $(d b h)$, canopy diameter $(c d)$, total height $(t h)$ and stipe height $(s h)$ were measured with tape measure and tread, respectively.

In the laboratory, the green samples were weighed in a precision scale $(0.001 \mathrm{~g})$, and placed in an oven with circulation and air renewal at $70^{\circ} \mathrm{C}$ until reaching constant weight. The relationships between the dry and fresh biomass of the samples were then used to calculate the total dry biomass of each tree. Furthermore, the samples were ground in a Willey type mill and the carbon contents were determined in the LECO C-144 equipment.

The descriptive statistical analysis was performed together with the graphical analysis of the biomass and carbon ratios with the variables $d b h, c d$, th and $s h$. Subsequently, the Kolmogorov-Smirnov test (p-value $\leq 0.01)$ was calculated to verify the normality of the variables involved in the study.

In addition, Pearson's linear correlation ( $r$ ) was used to verify the sense and the degree of association between the variables. Thereafter, the track analysis (path analysis) was calculated to verify the influence of direct 
and indirect factors of independent variables $(d b h, c d$, th and $s h$ ) about the dependent variables (biomass and carbon), in order to evaluate the cause-effect relationship between them.

The level of multicollinearity of the singular matrix $X^{\prime} X$ was established with the condition number $(\mathrm{CN}$ $=$ ratio between the largest and the smallest autovalue) of these matrices. In order to mitigate the effect of very high variance, the system of normal equations was modified by adding a constant $k$ to the values of the diagonal elements of the matrix.

The biomass and carbon of E. guineensis were estimated from the dependent variables $h t$, $h e$ and the combination $h t$.he . In total, five models were adjusted for each response variable, being three linear and two nonlinear.

$$
\begin{gathered}
y_{i}=\beta_{0}+\beta_{1} h t_{i}+\varepsilon_{i} \\
y_{i}=\beta_{0}+\beta_{1} h e_{i}+\varepsilon_{i} \\
y_{i}=\beta_{0}+\beta_{1}(h t * h e)_{i}+\varepsilon_{i} \\
y_{i}=\beta_{0}+h t_{i}^{\beta_{1}}+h e_{i}^{\beta_{2}}+\varepsilon_{i} \\
y_{i}=\beta_{0}+h e_{i}^{\beta_{1}}+\varepsilon_{i}
\end{gathered}
$$

Independent Adjustment

The simultaneous adjustment allows us to verify that the sum of the equations of each compartment is similar to that of the equation for total biomass above the ground, guaranteeing the additivity of the biomass components and improvement of the adjustment.

$$
\begin{gathered}
y_{\text {tree crown }}=\beta_{11}+\beta_{12} h e_{i}+\varepsilon_{i} \\
y_{\text {stipe }}=\beta_{21}+\beta_{22} h e_{i}+\varepsilon_{i} \\
y_{\text {total }}=\left(\beta_{11}+\beta_{12} h e_{i}\right)+\left(\beta_{21}+\beta_{22} h e_{i}\right)+\varepsilon_{i}
\end{gathered}
$$

Simultaneous Adjustment

The adjusted and precision statistics calculated to evaluate the performance of the models in the biomass and carbon estimates were the adjusted coefficient of determination (09), standard error of the estimate in percentage (10), Akaike's information criterion (11) and, for (12), to verify possible biases in the estimates and the homogeneity of the errors.

$$
\begin{gathered}
R_{a j}^{2}=1-\left[\left(\frac{\sum_{i=1}^{n}\left(y_{i}-\hat{y}_{i}\right)^{2}}{\sum_{i=1}^{n}\left(y_{i}-\bar{y}\right)^{2}}\right)\left(\frac{n-1}{n-p-1}\right)\right] \\
S y x \%=\frac{\sqrt{\frac{\sum_{i=1}^{n}\left(y_{i}-\hat{y}_{i}\right)^{2}}{n-p}}}{\bar{y}_{i}} 100 \\
\text { CIA }=n \ln \left(\sigma^{2}\right)+2(p+) \\
\text { Residues } \%=\frac{y_{i}-\hat{y}_{i}}{y_{i}} 100
\end{gathered}
$$

where: $y_{i}=$ observed variable; $\hat{y}_{i}=$ estimated variable; $\bar{y}=$ average of observed variables; $n=$ number of observations; $p=$ number of model parameters; $l n=$ natural logarithm; $\sigma^{2}=$ maximum likelihood estimator of the error variance.

\section{RESULTS}

The age of E. guinensis presented great amplitude (Table 1). The canopy diameter (cd) and the diameter (dbh) had the lowest values for coefficient of variation (CV), followed by total height (ht), age and height of scion (and). The biomass and carbon presented coefficient of variation with values between 24 and $31.52 \%$. All variables were normal by the Kolmogorov-Smirnov test for $\mathrm{p}$-value $\leq 0.01$.

Table 1. Normality test (KS) and descriptive statistics for the variables: age (years), crown biomass component (CBC), stipe biomass component (SBC), above-ground biomass component (AGBC), in $\mathrm{kg}$, crown carbon component (CCC), stipe carbon component (SCC), above-ground carbon component (AGCC), in $\mathrm{kg}$, diameter at the breast height $(d b h)$, crown diameter $(c d)$, total height $(t h)$ and stipe height $(s h)$ of Elaeis guineensis.

Tabela 1. Teste de normalidade (KS) e estatística descritiva para as variáveis idade (anos), componentes de biomassa copa (BCOP), estipe (BEST) e acima do solo (BTOT), em kg, componentes de carbono copa (CCOP), estipe (CEST) e acima do solo (CTOT), em kg, diâmetro à 1,3 m do solo (dap), diâmetro de copa $(d c)$, altura total $(h t)$ e altura do estipe $(h e)$ de Elaeis guineensis.

FLORESTA, Curitiba, PR, v. 49, n. 3, p. 421 - 430, jul/set 2019 


\begin{tabular}{cccccccccccc}
\hline Statistics & Age & CBC & SBC & AGBC & CCC & SCC & AGCC & $\boldsymbol{d} \boldsymbol{b h}(\mathbf{c m})$ & $\boldsymbol{c d}(\mathbf{c m})$ & $\boldsymbol{t h}(\mathbf{m})$ & $\begin{array}{c}\boldsymbol{s} \boldsymbol{(} \\
(\mathbf{m})\end{array}$ \\
\hline Minimum & 10.00 & 72.18 & 157.47 & 249.99 & 10.00 & 60.12 & 99.01 & 29.92 & 8.75 & 9.10 & 3.20 \\
Medium & 22.52 & 148.60 & 341.35 & 489.95 & 63.76 & 136.24 & 199.99 & 41.40 & 11.27 & 12.71 & 6.38 \\
Maximum & 36.00 & 226.34 & 533.08 & 704.70 & 98.48 & 211.90 & 287.11 & 51.57 & 13.15 & 18.20 & 12.45 \\
S & 6.62 & 45.83 & 101.67 & 136.24 & 20.10 & 40.67 & 51.66 & 5.08 & 1.13 & 2.17 & 2.23 \\
CV & 29.42 & 30.84 & 29.79 & 24.00 & 31.52 & 29.85 & 25.83 & 12.28 & 10.05 & 17.08 & 34.98 \\
KS (p-value) & 0.0383 & 0.0998 & 0.1502 & 0.1628 & 0.0693 & 0.1356 & 0.1442 & 0.3004 & 0.1042 & 0.0532 & 0.0654 \\
\hline
\end{tabular}

$\mathrm{KS}=$ Kolmogorov-Smirnov test for normality; CV = coefficient of variation (\%); $\mathrm{S}=$ Standard Deviation.

Pearson's analysis of linear correlation indicated that the biomass and carbon of the above ground soil showed a positive and statistically significant relationship ( $\mathrm{p}$-value $\leq 0.01$ ) for the variables measured, except for $c d$, but for these components the stipe height had the greatest direct effect (Table 2). For biomass and canopy carbon, only $c d$ showed significant and positive correlations, but the greatest direct effect on biomass $(0.695)$ and carbon (0.992) was the height of the stipe.

Table 2. Path analysis for direct and indirect effects of the age (years), diameter at the breast height ( $d b h)$, crown diameter $(c d)$, total height $(t h)$ and stipe height $(s h)$ on the canopy biomass components (CBC), stipe biomass components (SBC), above-ground biomass components (AGBC), in $\mathrm{kg}$, and on the crown carbon component (CCC), stipe carbon component (SCC), above-ground carbon component (AGCC) in Elaeis guineensis.

Tabela 2. Análise de trilha para efeitos diretos e indiretos da idade (anos), diâmetro à 1,3 m do solo (dap), diâmetro de copa $(d c)$, altura total $(h t)$ e altura do estipe (he) sobre a os componentes de biomassa copa (BCOP), estipe (BEST) e acima do solo (BTOT) e sobre os componentes de carbono copa (CCOP), estipe (CEST) e acima do solo (CTOT) em Elaeis guineensis.

\begin{tabular}{|c|c|c|c|c|c|c|c|c|c|c|c|c|}
\hline \multicolumn{2}{|c|}{ Variable } & \multirow{2}{*}{$\begin{array}{c}\text { immediat } \\
\text { e effect }\end{array}$} & \multicolumn{5}{|c|}{ Indirect effect } & \multirow{2}{*}{$\mathrm{r}$} & \multirow{2}{*}{$\mathrm{R}^{2}$} & \multirow{2}{*}{$\mathrm{e}$} & \multirow{2}{*}{$k$} & \multirow{2}{*}{$\mathrm{CN}$} \\
\hline Basic & Explanatory & & Age & $d b h$ & $c d$ & th & $s h$ & & & & & \\
\hline \multirow{5}{*}{$\mathrm{CBC}$} & Age & -0.684 & - & 0.021 & 0.176 & 0.011 & 0.600 & $0.090 \mathrm{~ns}$ & \multirow{5}{*}{0.48} & \multirow{5}{*}{0.72} & \multirow{5}{*}{0.05} & \multirow{5}{*}{31.6} \\
\hline & $d b h$ & 0.314 & -0.047 & - & -0.142 & 0.002 & 0.070 & $0.212 \mathrm{~ns}$ & & & & \\
\hline & $c d$ & 0.571 & -0.211 & -0.078 & - & 0.004 & 0.148 & $0.463^{*}$ & & & & \\
\hline & th & 0.013 & -0.571 & 0.013 & 0.185 & - & 0.653 & $0.336 \mathrm{~ns}$ & & & & \\
\hline & $s h$ & 0.695 & -0.591 & 0.031 & 0.122 & 0.012 & - & $0.304 \mathrm{~ns}$ & & & & \\
\hline \multirow{5}{*}{ SBC } & Age & 0.124 & - & 0.020 & -0.020 & -0.199 & 0.775 & $0.701 * *$ & \multirow{5}{*}{0.73} & \multirow{5}{*}{0.52} & \multirow{5}{*}{0.01} & \multirow{5}{*}{54.6} \\
\hline & $d b h$ & 0.282 & 0.009 & - & 0.016 & -0.042 & 0.090 & $0.357 *$ & & & & \\
\hline & $c d$ & -0.064 & 0.038 & -0.070 & - & -0.077 & 0.191 & $0.017 \mathrm{~ns}$ & & & & \\
\hline & th & -0.239 & 0.104 & 0.050 & -0.021 & - & 0.843 & $0.735 * *$ & & & & \\
\hline & $s h$ & 0.899 & 0.107 & 0.028 & -0.014 & -0.224 & - & $0.804 * *$ & & & & \\
\hline \multirow{5}{*}{ AGBC } & Age & -0.113 & - & 0.022 & 0.040 & -0.006 & 0.668 & $0.604 * *$ & \multirow{5}{*}{0.66} & \multirow{5}{*}{0.58} & \multirow{5}{*}{0.05} & \multirow{5}{*}{32.7} \\
\hline & $d b h$ & 0.317 & -0.008 & - & -0.032 & -0.001 & 0,77 & $0.369 *$ & & & & \\
\hline & $c d$ & 0.129 & -0.035 & -0.079 & - & -0.002 & 0.165 & $0.184 \mathrm{~ns}$ & & & & \\
\hline & th & -0.007 & -0.095 & 0.056 & 0.042 & - & 0.726 & $0.722 * *$ & & & & \\
\hline & $s h$ & 0.773 & -0.098 & 0.032 & 0.027 & -0.007 & - & $0.767 * *$ & & & & \\
\hline \multirow{5}{*}{$\mathrm{CCC}$} & Age & -0.890 & - & 0.023 & 0.208 & -0.207 & 0.966 & $0.091 \mathrm{~ns}$ & \multirow{5}{*}{0.56} & \multirow{5}{*}{0.66} & \multirow{5}{*}{0.01} & \\
\hline & $d b h$ & 0.338 & -0.062 & - & -0.168 & -0.044 & 0.112 & $0.180 \mathrm{~ns}$ & & & & \\
\hline & $c d$ & 0.676 & -0.274 & -0.084 & - & -0.081 & 0.238 & $0.482 * *$ & & & & 53.8 \\
\hline & th & -0.222 & -0.712 & 0.060 & 0.219 & - & 0.991 & $0.336 \mathrm{~ns}$ & & & & \\
\hline & $s h$ & 0.992 & -0.701 & 0.034 & 0.144 & -0.164 & - & $0.305 \mathrm{~ns}$ & & & & \\
\hline & Age & 0.102 & - & 0.022 & -0.010 & -0.204 & 0.780 & $0.690 * *$ & & & & \\
\hline & $d b h$ & 0.312 & 0.007 & - & 0.008 & -0.043 & 0.090 & $0.378^{*}$ & & & & \\
\hline SCC & $c d$ & -0.033 & 0.031 & -0.077 & - & -0.079 & 0.192 & $0.033 \mathrm{~ns}$ & 0.73 & 0.52 & 0.01 & 54.8 \\
\hline & th & -0.245 & 0.085 & 0.055 & -0.011 & - & 0.848 & $0.731 * *$ & & & & \\
\hline & $s h$ & 0.903 & 0.088 & 0.031 & -0.007 & -0.230 & - & $0.795 * *$ & & & & \\
\hline & Age & -0.150 & - & 0.023 & 0.053 & -0.009 & 0.670 & $0.579 * *$ & & & & \\
\hline & $d b h$ & 0.328 & -0.010 & - & -0.042 & -0.002 & 0.078 & $0.367^{*}$ & & & & \\
\hline AGCC & $c d$ & 0.171 & -0.046 & -0.081 & - & -0.002 & 0.165 & $0.212 \mathrm{~ns}$ & 0.64 & 0.60 & 0.05 & 31.6 \\
\hline & th & -0.011 & -0.125 & 0.058 & 0.055 & - & 0.729 & $0.706 * *$ & & & & \\
\hline & sh & 0.776 & -0.130 & 0.033 & 0.036 & -0.010 & - & $0.744 * *$ & & & & \\
\hline
\end{tabular}

$\overline{d b h}=$ diameter at $1,3 \mathrm{~m}$ above ground level; $c d=$ crown diameter; $t h=$ total height; $s h=$ height of stipe; $\mathrm{r}=$ Pearson correlation coefficient; $\mathrm{R}^{2}$ $=$ Coefficient of determination; $\mathrm{e}=$ Effect of the residual variable; $\mathrm{k}=$ constant $\mathrm{k}$ included in the main diagonal of matrix $\mathrm{XX}$; $\mathrm{CN}=\mathrm{condition}$ number; $\mathrm{CBC}=$ Cup biomass; $\mathrm{SBC}=$ Stimulus biomass; $\mathrm{AGBC}=$ above-ground biomass; $\mathrm{CCC}=\mathrm{Cup}$ carbon; $\mathrm{SCC}=\mathrm{Stoned}$ carbon; $\mathrm{AGCC}=$ above-ground carbon $;{ }^{* *}=$ significant correlation $(\mathrm{p}$-value $\leq 0.01) ;{ }^{*}=$ significant correlation $(\mathrm{p}$-value $\leq 0.05)$; ${ }^{\mathrm{ns}}=$ non-significant correlation (p-value $\leq 0.01)$. 
The direct effect of the variable stem height $(s h)$ was positive and high for total biomass and total carbon with a value close to 0.773 and 0.776 and a direct effect superior to the residual effect, reason for it to be used in modeling. On the other hand, for the variable total height $(t h)$, its direct effect was negative, although weak for both basic variables, with a value of -0.007 and 0.011 (Table 2), with its use in modeling being not recommended. It can be seen that the significance and great magnitude of the correlation of $t$ th on biomass and carbon of the stipe components and above the soil was due to its relation with the height of the stipe (Table 2). Table 2 also shows the statistics adjustment of the track analysis for each biomass and carbon component.

Moreover, the estimated coefficients of the models tested for biomass and total carbon of E. guineensis presented statistical significance ( $p$-value $\leq 0.01$ ), except for the intercept of model (01), which was not significant for both dependent variables (Table 3). The adjusted equations in the present study presented adjustment and precision statistics with small variation among the models tested. When the estimates of biomass and carbon from the same model are compared, it is noted that there are slightly better results for the biomass equations.

Table 3. Estimated coefficients and statistics of adjustment and accuracy of independently tested models in order to estimate biomass and above-ground total carbon, stipe and crown of Elaeis guineensis.

Tabela 3. Coeficientes estimados e estatísticas de ajuste e precisão dos modelos testados independente para estimar a biomassa e carbono total acima do solo, estipe e copa de Elaeis guineensis.

\begin{tabular}{|c|c|c|c|c|}
\hline Equations & $R_{a j}^{2}$ & Syx $(\%)$ & CIA & White \\
\hline \multicolumn{5}{|c|}{ Above-Ground Total Biomass } \\
\hline$y_{i}=-20.4099^{*}+40.9619 \cdot h t_{i}$ & 0.546 & 15.74 & 454.36 & $1.78^{\mathrm{ns}}$ \\
\hline$y_{i}=327.6854+42.2393 \cdot h e_{i}$ & 0.668 & 14.44 & 448.82 & $3.24^{\mathrm{ns}}$ \\
\hline$y_{i}=327.6854+2.0178(h t \cdot h e)_{i}$ & 0.569 & 15.33 & 452.67 & $2.24^{\mathrm{ns}}$ \\
\hline$y_{i}=310.7+h t_{i}^{1.896}+h e_{i}^{2.1567}$ & 0.541 & 15.81 & 453.63 & $2.06^{\mathrm{ns}}$ \\
\hline$y_{i}=399.6+h e_{i}^{2.3895}$ & 0.529 & 16.03 & 455.53 & $3.14^{\mathrm{ns}}$ \\
\hline \multicolumn{5}{|c|}{ Above-Ground Total Carbon } \\
\hline$y_{i}=-6.7193^{*}+16.5825 \cdot h t_{i}$ & 0.522 & 16.39 & 399.53 & $4.06^{\mathrm{ns}}$ \\
\hline$y_{i}=95.7076+19.5824 \cdot h e_{i}$ & 0.582 & 15.32 & 395.22 & $6.91^{\mathrm{ns}}$ \\
\hline$y_{i}=134.7746+0.8101(h t \cdot h e)_{i}$ & 0.534 & 16.17 & 398.66 & $4.62^{\mathrm{ns}}$ \\
\hline$y_{i}=115.1+h t_{i}^{1.5789}+h e_{i}^{1.8373}$ & 0.525 & 16.32 & 398.26 & $4.78^{\mathrm{ns}}$ \\
\hline$y_{i}=155.2+h e_{i}^{2.0350}$ & 0.520 & 16.42 & 399.64 & $5.87^{\mathrm{ns}}$ \\
\hline \multicolumn{5}{|c|}{ Stipe Biomass } \\
\hline$y_{i}=-82.3115^{*}+34.0459 \cdot h t_{i}$ & 0.555 & 18.35 & 441.39 & $2.80^{\mathrm{ns}}$ \\
\hline$y_{i}=118.8511+36.2928 \cdot h e_{i}$ & 0.674 & 15.72 & 431.47 & $1.40^{\mathrm{ns}}$ \\
\hline$y_{i}=201.1545+1.7456(h t \cdot h e)_{i}$ & 0.630 & 16.75 & 435.52 & $1.65^{\mathrm{ns}}$ \\
\hline$y_{i}=209.9+h t_{i}^{1.6472}+h e_{i}^{2.2371}$ & 0.602 & 17.35 & 436.78 & $2.48^{\mathrm{ns}}$ \\
\hline$y_{i}=259.4+h e_{i}^{2.3404}$ & 0.606 & 17.27 & 431.49 & $1.45^{\mathrm{ns}}$ \\
\hline \multicolumn{5}{|c|}{ Stipe Carbon } \\
\hline$y_{i}=-32.4093^{*}+13.5476 \cdot h t_{i}$ & 0.552 & 18.42 & 382.82 & $4.12^{\mathrm{ns}}$ \\
\hline$y_{i}=48.1932+14.3547 \cdot h e_{i}$ & 0.661 & 16.02 & 373.85 & $0.90^{\mathrm{ns}}$ \\
\hline$y_{i}=80.7281+0.6906(h t \cdot h e)_{i}$ & 0.618 & 17.00 & 377.67 & $2.36^{\mathrm{ns}}$ \\
\hline$y_{i}=77.1683+h t_{i}^{1.2555}+h e_{i}^{1.9123}$ & 0.610 & 17.20 & 377.41 & $2.48^{\mathrm{ns}}$ \\
\hline$y_{i}=96.0938+h e_{i}^{1.9794}$ & 0617 & 17.04 & 377.81 & $1.03^{\mathrm{ns}}$ \\
\hline \multicolumn{5}{|c|}{ Crown Biomass } \\
\hline$y_{i}=61.8953+6.9164 \cdot h t_{i}$ & 0.083 & 28.19 & 414.47 & $2.21^{\mathrm{ns}}$ \\
\hline$y_{i}=111.8603+5.947 \cdot h e_{i}$ & 0.058 & 28.56 & 415.34 & $1.70^{\mathrm{ns}}$ \\
\hline$y_{i}=126.5284+0.2722(h t \cdot h e)_{i}$ & 0.045 & 28.78 & 415.79 & $5.45^{\mathrm{ns}}$ \\
\hline$y_{i}=96.9745+h t_{i}^{1.5254}+h e_{i}^{0.7472}$ & 0.042 & 28.81 & 414.84 & $3.31^{\mathrm{ns}}$ \\
\hline$y_{i}=129.2+h e_{i}^{1.6019}$ & 0.044 & 28.79 & 415.81 & $1.78^{\mathrm{ns}}$ \\
\hline \multicolumn{5}{|c|}{ Crown Carbon } \\
\hline$y_{i}=25.6956+3.0344 \cdot h t_{i}$ & 0.084 & 28.81 & 361.70 & $1.95^{\mathrm{ns}}$ \\
\hline$y_{i}=47.5175+2.6247 \cdot h e_{i}$ & 0.059 & 29.19 & 362.53 & $1.60^{\mathrm{ns}}$ \\
\hline$y_{i}=54.0471+00.1195(h t \cdot h e)_{i}$ & 0.045 & 29.42 & 363.03 & $5.28^{\mathrm{ns}}$ \\
\hline$y_{i}=35.5457+h t_{i}^{1.2742}+h e_{i}^{0.6133}$ & 0.047 & 29.36 & 361.89 & $4.46^{\mathrm{ns}}$ \\
\hline$y_{i}=52.668+h e_{i}^{1.3098}$ & 0.052 & 29.31 & 362.79 & $1.75^{\mathrm{ns}}$ \\
\hline
\end{tabular}

$R_{a j}^{2}=$ adjusted coefficient of determination; $\operatorname{Syx}=$ standard error of the estimate; $C I A=$ Akaike information criteria; ${ }^{\mathrm{ns}}=$ not significant at $5 \%$ probability of error.

Table 3 shows that, for biomass and carbon of the stipe, the best model was (02), with the explanatory variable being the height of the stipe. In the model (01) for biomass and carbon of the stipe the intercept was not 
significant. For the crown, only the model (05) obtained significant intercept and angular coefficient, nevertheless all the equations presented similar adjustment statistics.

All models, except for (02), tend to make similar estimates; thus, models (01), (03), (04) and (05) can be considered suitable for estimating biomass and above-ground carbon, according to the residue chart analysis (Figure 1). However, the equation (05) presented a more satisfactory fit and precision statistics. The best performance of this equation is directly related to the higher correlation between the dependent variables with $s h$. The equations (01), (03), (04) and (05), adjusted for biomass and total carbon above the soil, presented residues distributed between $\pm 50 \%$. Biased estimates were obtained in equation (02), mainly to overestimate the individuals biomass and carbon. The same tendencies can be evidenced for the stipe, but with residues between $\pm 60 \%$ (Figure 2). Similar results were found for biomass and crown carbon estimates, with residues between $\pm 60 \%$ (Figure 3 ).
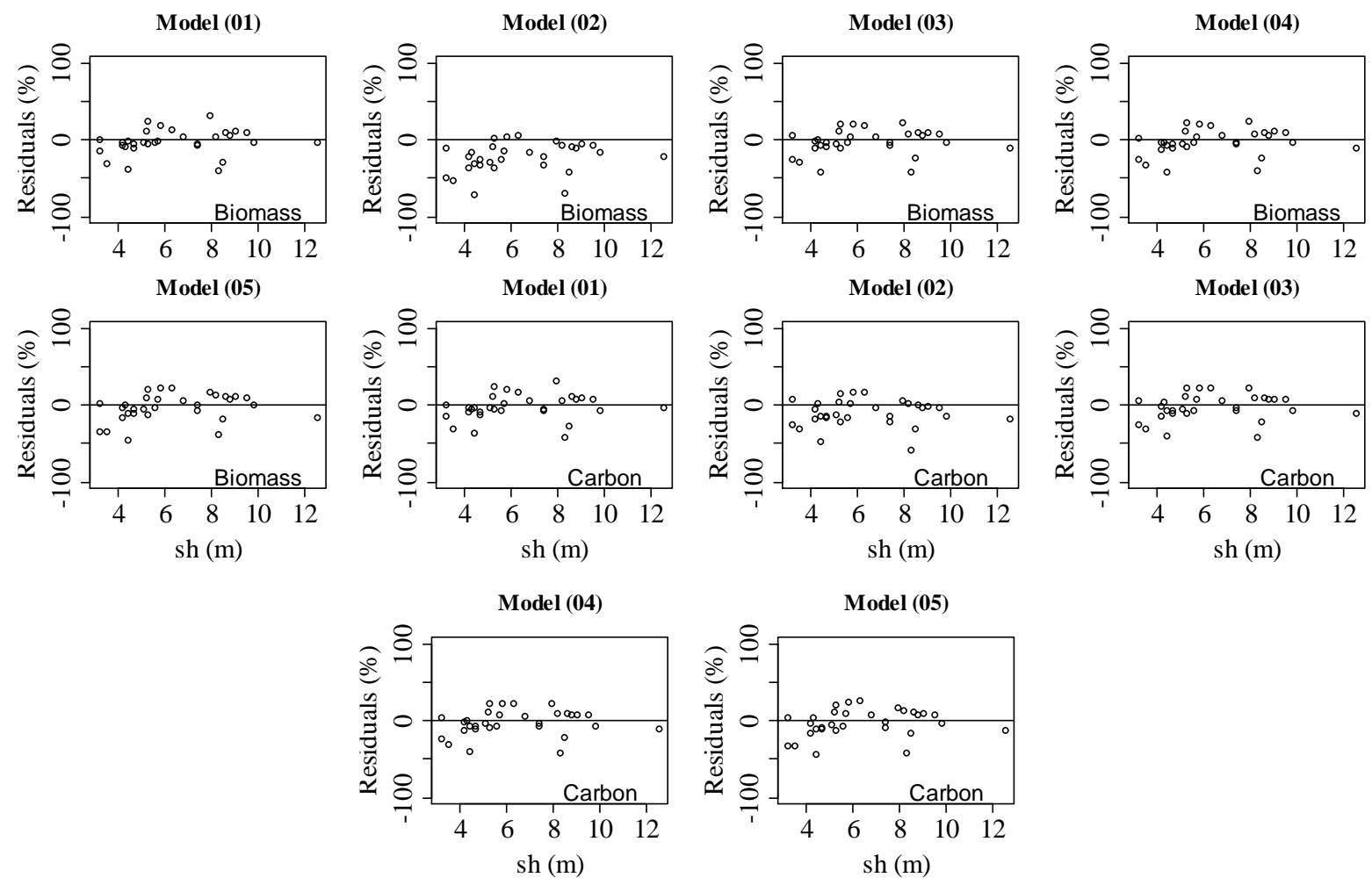

Figure 1. Residual dispersion of the tested models to estimate the biomass and above-ground total carbon of the Elaeis guineensis species as a function of the height of the stipe $(s h)$.

Figura 1. Dispersão de resíduos dos modelos testados para estimar a biomassa e carbono total acima do solo da espécie Elaeis guineenses em função da altura do estipe (he).

For the estimation of biomass and carbon, the best model in relation to $\mathrm{R}^{2} \mathrm{aj}$ was for the compartment stipe. The lowest Syx\% was also obtained for the estimates in biomass and carbon (Table 03). With these statistics and considering the graphical analysis of the residues, the model (02) was selected as the best for the biomass and carbon components of the stipe and crown components. Additionally, this choice is also related to the ease of adjustment, since it is a linear model as well as because in the simultaneous adjustment the nature of the component, models must be the same.

Furthermore, simultaneous estimates for biomass and carbon presented satisfactory and similar results (Table 4 and Figure 4) when evaluated and compared with the independent adjustment statistics; it must be considered that only the simultaneous adjustment guarantees the additivity of the component estimates. In this way, it is possible to guarantee the quality of the total estimate (additivity principle) of biomass and carbon for each individual, the result of the sum of the equations of each compartment is the same as that of the equation applied for the total. 

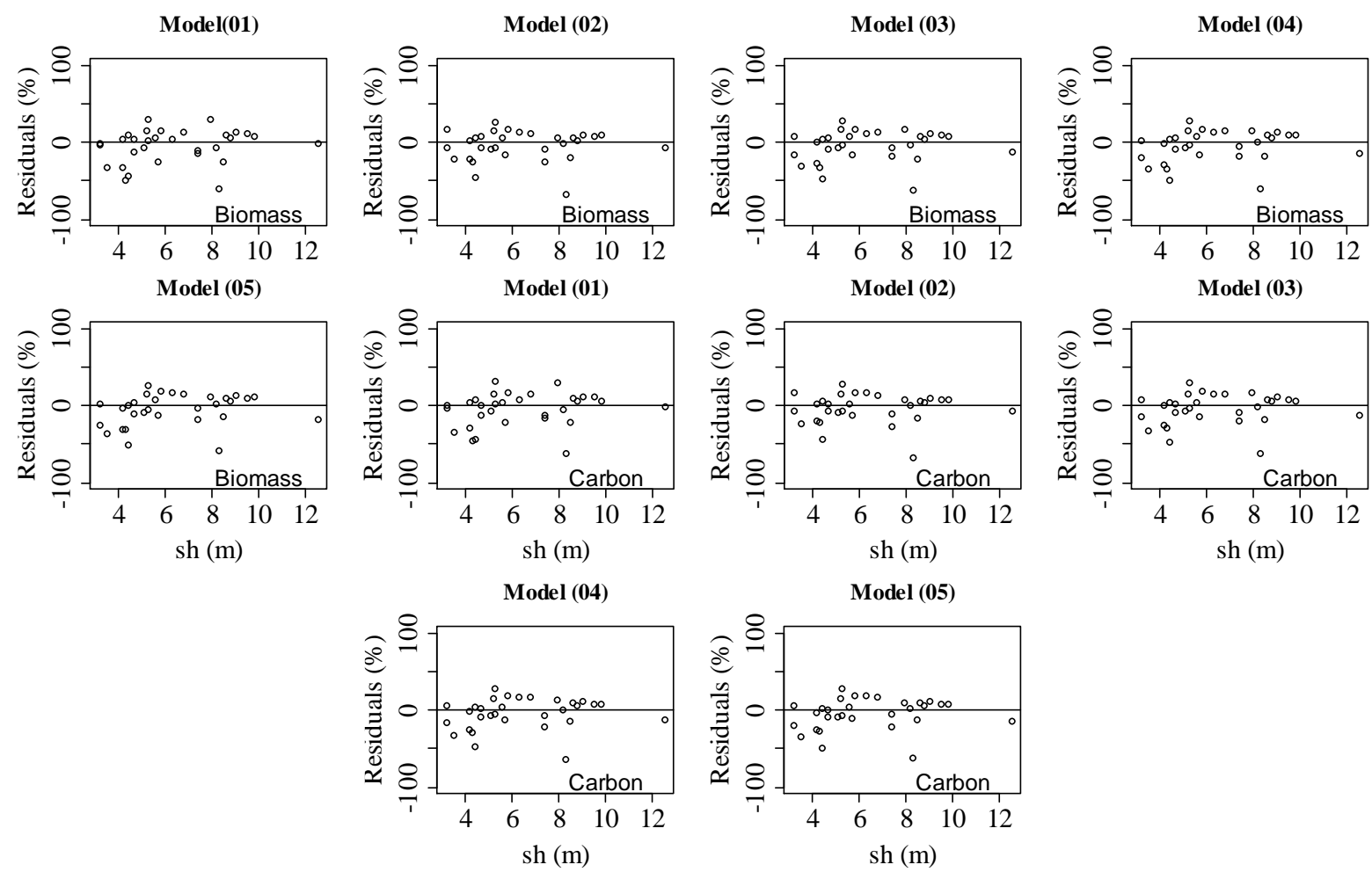

Figure 2. Residual dispersion of the tested models to estimate the stipe biomass and stipe carbon of Elaeis guineensis species in function of the stipe height $(s h)$.

Figura 2. Dispersão de resíduos dos modelos testados para estimar a biomassa e carbono do estipe da espécie Elaeis guineensis em função da altura do estipe (he).

Table 4. Estimated coefficients and statistics of adjustment and accuracy of the models fitted simultaneously to estimate the biomass and carbon content of Elaeis guineensis.

Tabela 4. Coeficientes estimados e estatísticas de ajuste e precisão dos modelos testados simultaneamente para estimar a biomassa e carbono de Elaeis guineensis.

\begin{tabular}{|c|c|c|c|c|}
\hline Model & $R_{a j}^{2}$ & $\operatorname{syx}(\%)$ & CIA & White \\
\hline \multicolumn{5}{|l|}{ Biomass } \\
\hline$y$ stipe $=107.5853+36.6337 \cdot h e$ & 0.667 & 17.70 & 437.4 & $1.23^{\mathrm{ns}}$ \\
\hline$y$ crown $=108.7581+6.24321 \cdot h e$ & 0.092 & 29.38 & 416.6 & $1.46^{\mathrm{ns}}$ \\
\hline$y$ total $=(107.5853+36.6337 \cdot h e)+(108.7581+6.24321 \cdot h e)$ & 0.574 & 16.62 & 455.5 & $2.17^{\mathrm{ns}}$ \\
\hline \multicolumn{5}{|l|}{ Carbon } \\
\hline$y$ stipe $=43.87693+14.4664 \cdot h e$ & 0.632 & 18.11 & 380.1 & $1.44^{\mathrm{ns}}$ \\
\hline y crown $=46.23992+2.74034 \cdot h e$ & 0.093 & 30.01 & 363.8 & $1.73^{\text {ns }}$ \\
\hline$y$ total $=(43.87693+14.4664 \cdot h e)+(46.23992+2.74034 \cdot h e)$ & 0.540 & 17.52 & 401.5 & $2.47^{\mathrm{ns}}$ \\
\hline
\end{tabular}

$R_{a j}^{2}=$ adjusted coefficient of determination;Syx = standard error of the estimate; $C I A=$ Akaike information criteria; $s h=$ stipe height; ${ }^{\mathrm{ns}}=$ not significant at $5 \%$ probability of error. 

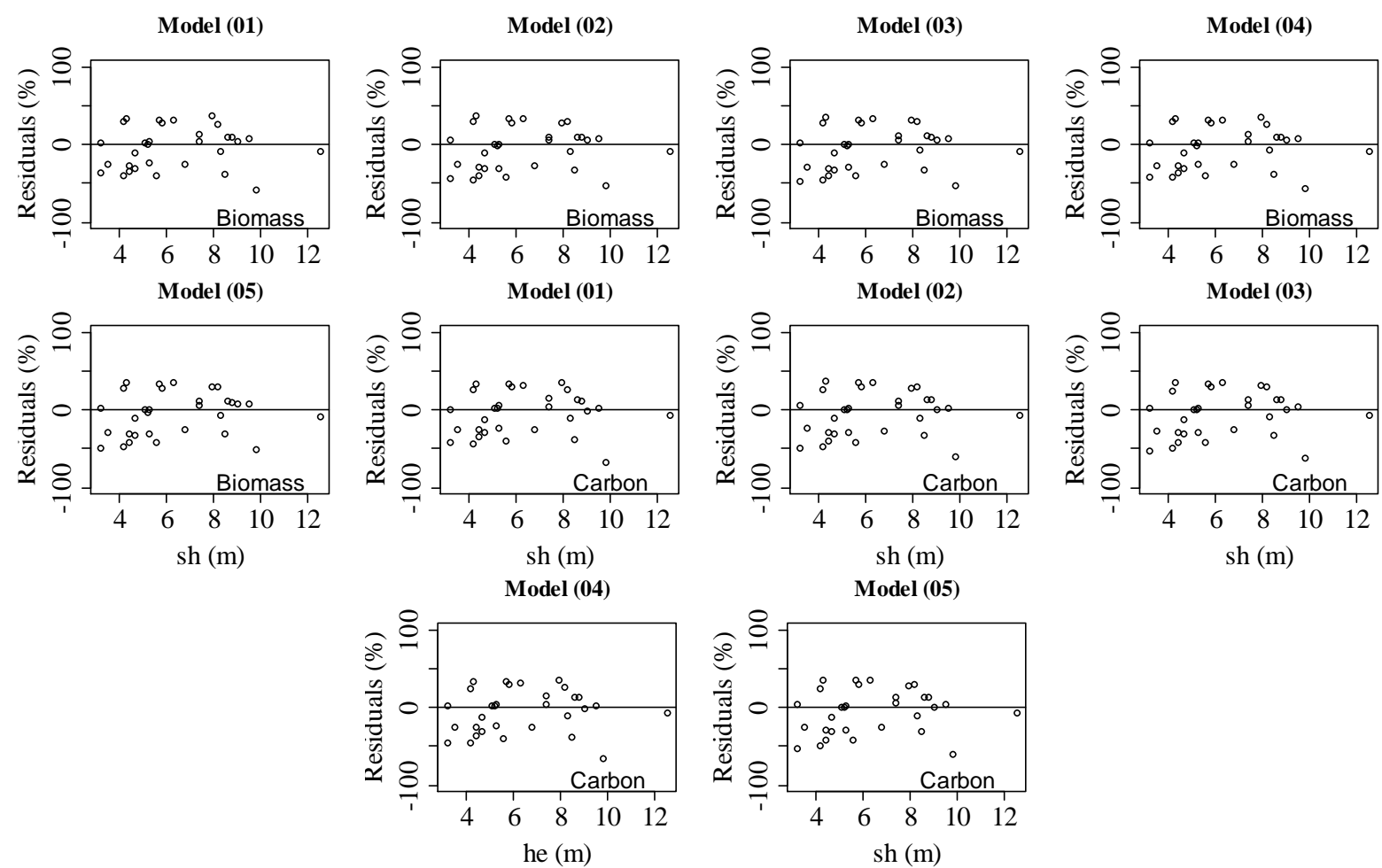

Figure 3. Residual dispersion of the tested models to estimate the crown biomass of Elaeis guineensis species as a function of the stipe height $(s h)$.

Figura 3. Dispersão de resíduos dos modelos testados para estimar a biomassa da copa da espécie Elaeis guineensis em função da altura do estipe (he).
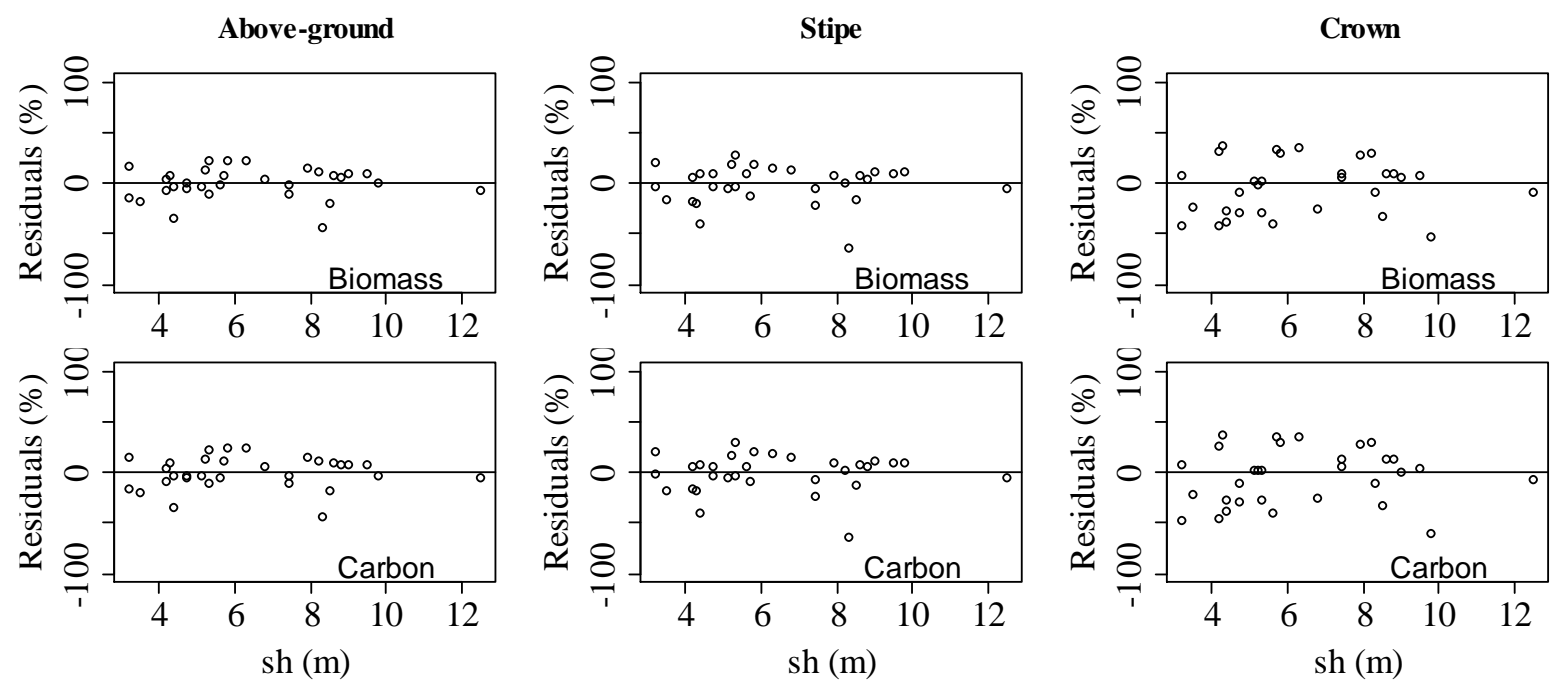

Figure 4. Residual dispersion of the models fitted simultaneously to estimate the biomass and carbon content of Elaeis guineensis species as a function of the stipe height $(s h)$.

Figura 4. Dispersão de resíduos dos modelos ajustados simultaneamente para estimar a biomassa e carbono da espécie Elaeis guineensis em função da altura do estipe (he).

\section{DISCUSSION}

In the track analysis, the variables presented weak multicollinearity ( $\mathrm{CN}$ between 31.6 and 54.8), since Montgomery et al. (2012) state that if the CN is less than 100, multicollinearity does not become a problem (weak multicollinearity), $\mathrm{CN}$ ranging from 100 to 1000 multicollinearity is known as moderate to strong and if $\mathrm{CN}$ is 
greater than 1000, there are indications of severe multicollinearity (MOREIRA et al., 2013). As evidenced by track analysis, only equations with the variable $s h$ used as independent variable were selected, model (02), for crown and stipe. In the use of track analysis, great care must be taken with multicollinearity, when possible the variables that cause them must be eliminated, but when it is not possible, the lowest possible value of $\mathrm{k}$ must be used, since high values of $\mathrm{k}$ can bring into perspective the estimates of direct and indirect effects (OLIVOTO et al., 2017).

Mognon et al. (2015), in studies with total biomass modeling with Dendrocalamus asper, obtained less robust results in the precision statistics, in which the best equation presented $\mathrm{R}^{2}$ aj of 0.59 and Syx (\%) of 17.12. In turn, Cassol et al. (2016), with studies for the production of biofuels with palm oil, obtained for biomass similar standard error of estimation and higher adjusted coefficient of determination due to the use of the Neperian logarithmic and the variable age. For the present study, no transformations of the original data were performed, since they were normal and, yet, when using this technique, there were problems with the estimates being systematically biased.

By comparing the two ways of adjusting the equations, independent and simultaneous, it can be seen that the simultaneously adjusted equations presented similar precision statistics with those of the independent fit. Nonetheless, biological consistency should be considered in adjustments that consider the biomass components together with the total biomass. Thus, only the fitted models should be used to predict the total biomass and its components of E. guineensis. However, the independent adjustment was necessary to make the choice of the best model for each component, only after this step the simultaneous adjustment was made.

By means of graphical analysis of the residues, a trend in the biomass and carbon estimates of the crown of E. guineensisis was evidenced, these tendentious estimates may be associated with the morphological characteristics of the palm. This species presents a secondary growth in lower intensity when compared with primary or apical growth. With a more in-depth analysis of the original data it can be verified that canopy biomass presents a more stable trend in all the years of evaluation, i.e., the biomass and carbon variation of the canopy presents a small variation between the ages evaluated, while the height of the sprout shows positive linear growth, that is, the biomass increases with increasing age and with the height of the stipe.

The species shows a decrease in the average diameter of the stipe and a small growth in the last 10 years of study in relation to the average diameter. Regarding the crown of E. guineenses, there is no significant difference in relation to growth over the 26 years (Table 01). The expressive response is observed in the stipe, with increased growth and better adjustments, being related to the morphological characteristics of the species.

\section{CONCLUSION}

- Simultaneous adjustment presented more satisfactory results in modeling to estimate biomass and carbon components and total biomass in relation to the independent estimate.

- Only the heights showed significant correlations and the track analysis revealed that only the height of the stipe has a significant direct effect.

- The dependent variable height of stipe obtained the best fit for biomass and total carbon estimates.

- For the stipe components, the best estimate of biomass and carbon was for the linear model as a function of the height of the stipe, and for the crown, the most appropriate was also for the height of the stipe with the nonlinear model.

\section{REFERENCES}

AlVARES, C. A.; STAPE, J. L.; SENTElHAS, P. C.; GONÇALVES, J. L. M.; SPAROVEK, G. Ko“ppen's climate classification map for Brazil. Meteorologische Zeitschrift, v. 22, n. 6, p. 711-728, 2013.

BEHlinG, A.; PÉllico NETTO, S.; SANQUETTA, C.R.; CORTE, A.P.D.; AFFlECK, D. L. R.; RODRIGUES, A. L.; BEHLING, M. Critical analyses when modeling tree biomass to ensure additivity of its components. Anais da Academia Brasileira de Ciências, v. 90, n. 2, p. 1759-1774, 2018.

BORGES, A. C. P.; SILVA, M. S.; ALVES, C. T.; TORRES, E. A. Energias renováveis: uma contextualização da biomassa como fonte de energia. REDE, Fortaleza, v.10, n.2, p.23-36, 2016.

CASSOL, H. L.G.; MELO, L.C.; MENDES, F. S.; FONSECA, R.; SANQUETTA, C.R. Redução de emissões de $\mathrm{CO}_{2}$ pela produção de biocombustíveis a partir de óleo de dendê na amazônia brasileira. Floresta, Curitiba, PR, v. 46, n. 1, p. 135-144, jan. / mar. 2016.

FLORESTA, Curitiba, PR, v. 49, n. 3, p. 421 - 430, jul/set 2019. 
CORTE, A. P. D.; SILVA, F.; SANQUETTA, C. R. Fator de expansão de biomassa e razão de raízes-parte aérea para Pinus spp. Plantadas no sul do Brasil. Floresta, Curitiba, v. 42, n. 4, p.755-768, out/dez, 2012.

Goldemberg, J.; VILlanueva, L. D. Energia, Meio Ambiente \& desenvolvimento. São Paulo: Editora da Universidade de São Paulo, 2003.

IBGE, INSTITUTO BRASILEIRO DE GEOGRAFIA E ESTATÍSTICA. Manual técnico da vegetação brasileira. Rio de Janeiro, 2. ed. revista e ampliada, 2012, $271 \mathrm{p}$.

KOZAK, A. Methods of ensuring additivity of biomass components by regression analysis. The Forestry Chronicle, v. 46, n. 5, p. 402-404, 1970.

LORENZI, H.; SOUZA, H. M.; CERQUEIRA, L. S. C.; FERREIRA, E.; COSTA, J. T. M. Palmeiras brasileiras e exóticas cultivadas. Instituto Plantarum. Nova Odessa. 2004. 1ed. 415 p.

MOGNON, F.; RODRIGUES, A.L., SANQUETTA, C.R.; CORTE, A. P. D.; NOVAES, A.B.; BLUM, C. T. Alocação e modelagem da biomassa em Dendrocalamus asper. Floresta, Curitiba, PR, v. 45, n. 1, p. 1 - 10, jan. / mar. 2015.

MONTGOMERY, D. C.; PECK, E. A.; VINING, G. G. Introduction to linear regression analyses. Wiley, 2012, $504 \mathrm{p}$.

MOREIRA, S. O.; GONÇALVES, L. S. A.; RODRIGUES, R.; SUDRE, C. P.; AMARAL JUNIOR, A. T.; MEDEIROS, A. M. Correlações e análise de trilha sob multicolinearidade em linhas recombinadas de pimenta (Capsicu mannuum L.). Revista Brasileira de Ciências Agrárias. Recife, v.8, n.1, p.15-20, 2013.

OLIVEIRA, N. M. L.; ALVES, S. C.; DANTAS, S. B. S.; MARTINS, E. C. A. Reaproveitamento de resíduos da cadeia do biodiesel obtido a partir do óleo de palma (Elaeis guineenses). Bioenergia em Revista: Diálogos, Piracicaba, v.7, n.1, 2017.

OLIVOTO, T.; SOUZA, V. Q. S.; NARDINO, M.; CARVALHO, I. R.; FERRARI, M.; PELEGRIN, A. J.; SZARESKI, V. J.; SCHIMIDT, D. Multicollinearity in Path Analysis: A Simple Method to Reduce Its Effects. Agronomy Journal, v.109, n.1, p.131-142, 2017.

PARRESOL, B. R. Additivity of nonlinear biomass equations. Canadian Journal of Forest Research, v.31, p. 865-878, 2001.

RIBEIRO, S. C.; FEHRMANN, L.; SOARES, C. P. B.; JACOVINE, L. A. G.; KLEINN, C.;GASPAR, R. O. Above and belowground biomass in a Brazilian Cerrado. Forest Ecology and Management, Amsterdam, v. 262, n. 3, p. 491-499, ago. 2011.

RIOS, S. A; CUNHA, R N. V.; LOPES, R.; BARCELOS, E. Recursos Genéticos de Palma de Óleo (Elaei sguineenses Jacq.) e Caiaué (Elaeis oleifera H.B.K.) Cortés). Manaus: Embrapa, 2012. 44 p.

SANTOS, H. G.; JACOMINE, P. K. T.; ANJOS, L. H. C.; OLIVEIRA, V. A.; LUBRERAS, J. F.; COELHO, M. R.; ALMEIDA, J. A.; CUNHA, T. J. F.; OLIVEIRA, J. B. Sistema Brasileiro de Classificação de Solos. 3. ed. Brasília, EMBRAPA, 353p, 2013.

SOARES, C. P. B.; LEITE, H. G.; GORGENS, E. B. Equações para estimar o estoque de carbono no tronco de árvores individuais e em plantios comerciais de eucalipto. Revista Árvore, Viçosa, v. 29, n. 5, p. 711-718, 2005.

SANQUETTA C. R.; PELliCO NETO, S.; CORTE, A. P. D.; RODRIGUES, A. L.; BEHLING, A.; SANQUETTA, M. N. I. Quantifying biomass and carbon stocks in oil palm (Elaeis guineenses Jacq.) in Northeastern Brazil. African Journal Agricultural Research, Lagos, v. 10, n. 43, p.4067-4075, 2015.

SANQUETTA, C. R.; CORTE, A. P. D.; BALBINOT, R.; ZILLIOTTO, M. A. B. Proposta metodológica para quantificação e monitoramento do carbono estocado em florestas plantadas. In: Carlos Roberto Sanquetta; Marco Aurélio Zilliotto (orgs.). Mercado de carbono: mercado e ciência. Curitiba: UFPR, v.1, p.120-150. 2004. 